\title{
KNOWLEDGE, PERCEPTION, MYTHS AND HEALTH SEEKING BEHAVIOUR ON INFERTILITY AMONG MEN AND WOMEN ATTENDING SELECTED HOSPITALS IN OGUN STATE, NIGERIA
}

\section{Amusan Ayorinde Olugbenga ${ }^{1}$, Professor Agbede Catherine O. ${ }^{2}$}

\author{
${ }^{1}$ Department of Public Health, School of Public and Allied Health, Babcock University, \\ Ilishan-Remo, Ogun State, Nigeria. \\ Email: ayoamusan09@yahoo.com; Tel: +2348039125256
${ }^{2}$ Department of Public Health, School of Public and Allied Health, Babcock University, Ilishan-Remo, Ogun State, Nigeria. Email address: agbedec@babcock.edu.ng

Cite this article:

Amusan A.O., Agbede C.O. (2021), Knowledge, Perception, Myths and Health Seeking Behaviour on Infertility Among Men and Women Attending Selected Hospitals in Ogun State, Nigeria. African Journal of Health, Nursing and Midwifery 4(4), 86-100. DOI: 10.52589/AJHNMFFPNCD90.

\section{Manuscript History}

Received: 5 June 2021

Accepted: 5 July 2021

Published: 20 July 2021

Copyright $\odot 2020$ The Author(s) This is an Open Access article distributed under the terms of Creative Commons AttributionNonCommercial-NoDerivatives 4.0 International (CC BY-NC-ND 4.0 ), which permits anyone to share, use, reproduce and redistribute in any medium, provided the original author and source are credited.
ABSTRACT: Background: Infertility is medically defined as the inability to achieve a pregnancy after a year or more of regular unprotected sexual intercourse. It causes great worry and sorrow for many couples in Africa, especially for the women. Medical evidence shows that men and women usually have the same rates of infertility. This study therefore investigated the knowledge, perception, myths and health seeking behaviour on infertility among men and women attending selected hospitals in Ogun state, Nigeria. Methods: The study employed descriptive cross-sectional design. Multi-stage sampling technique was used to select 272 participants for the study. A 70-item validated semistructured questionnaire with Cronbach's alpha of 0.77 was used to collect data. The knowledge variable was measures on 27point rating score and perception was measured on 27-point scale. The health seeking behaviour was measured on 9-point scale. Frequency, correlation, and linear regression analysis were conducted to give statistical responses to the research questions and hypotheses using IBM-SPSS version 25. Results: The mean age of the respondents was $33.27 \pm 8.7$ years and 204(75\%) of the respondents were female. Most 172(63.2\%) of the respondents were of the Christian faith, 149(54.8) of the respondents had a tertiary education, less than half 131(48.2\%) of the respondents were self-employed and majority of the respondents were married 220(80.9\%). The respondents knowledge on infertility measured on a 27points knowledge

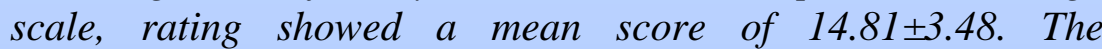
respondents' perception on infertility measured on a 27-point rating scale, showed a mean of $14.45 \pm 3.52$, and the respondents health seeking behaviour was measured on a 9-points scale rating with a respondents mean score of 5.20 \pm 1.97 . Majority $238(87.5 \%)$ of the respondents knew that infertility can be prevented, of those who stated that infertility can be prevented reported the following means, health education on reproduction 225(94.5\%), fertility awareness 226 (95\%), and early treatment 
of sexually transmitted disease 236(99.1\%) Majority 209(76.8\%) of the respondents knew that infertility can be treated. Less than half $100(36.8 \%)$ of the respondents disagreed that infertility is not a serious problem, while 91(33.5\%) opposed to the idea that infertility is only serious in African society. The knowledge and health seeking behaviour $(r=0.22 ; p=0.00)\left(R=0.22 ; R^{2}=0.04\right.$; $p<0.05)$, perception and health-seeking behaviour $(r=0.14$; $p=0.02)\left(R=0.14 ; R^{2}=0.02 ; p<0.05\right)$. Conclusion: In conclusion the respondents had adequate knowledge and perception of infertility. Majority of the respondents' health seeking behaviour included the use of traditional and orthodox medicine. Majority of the respondents had poor health-seeking behaviour.

KEYWORDS: Knowledge, Perception, Myths, Infertility, Health Seeking Behaviour, Nigeria.

\section{INTRODUCTION}

\section{Background}

Infertility is medically defined as the inability to achieve a pregnancy after a year or more of regular unprotected sexual intercourse. It affects the entire women`s life ${ }^{(1)}$. It is reported as being 16 times more frequent than maternal mortality. ${ }^{(2)}$ Globally, 56\% of women with infertility are having problem seeking help. ${ }^{(3)}$ From the epidemiological perspective, infertility is defined as inability of a woman of reproductive age who is at risk of pregnancy, to conceive despite continuous unprotected sexual intercourse for two years or more ${ }^{(4)}$. Infertility can be primary or secondary. Primary infertility is the inability to conceive in a couple who have had no previous pregnancy ${ }^{(5)}$. Whereas secondary infertility is the inability to conceive in a couple who have had at least one previous pregnancy which may have ended in live birth, still birth, miscarriage, ectopic pregnancy or induced abortion ${ }^{(5)}$.

It is also estimated that $10 \%$ of women are affected with infertility worldwide ${ }^{(4)}$. In 2010 , among women aged 20-44years that were exposed to the risk of pregnancy, $1.9 \%$ were unable to conceive. Out of women who had had at least one live birth and were exposed to the risk of pregnancy, $10.5 \%$ were unable to conceive again ${ }^{(6)}$. In the United Kingdom (UK), $2.4 \%$ of women aged 40-55 years had unresolved infertility with no pregnancies (primary), and a further $1.9 \%$ had been pregnant but not achieved a live birth ${ }^{(7)}$. According to the Center for Disease Control and Prevention ${ }^{(8)}$, approximately $10 \%$ or 6.1 million women in the United States struggle with infertility.

In Africa the prevalence rate of infertility may be as high as $20-30 \%$ in some areas, and vary from region to region even within the same country. Infertility prevalence is highest in South Asia, Sub-Saharan Africa, North Africa/Middle East, and Central/Eastern Europe and Central Asia ${ }^{(6)}$. In sub-Saharan Africa, primary infertility is much less prevalent than secondary infertility ${ }^{(9)}$. These disparities are reported to be the result of the high prevalence of untreated sexually transmitted infections, abortion and postpartum infections ${ }^{(4,10)}$. It has been reported that, the exact prevalence of infertility in developing countries is unknown due to a lack of 
registration and scarcity of empirical investigations in the area ${ }^{(11)}$. The overall burden of infertility is significant, likely underestimated, and has not displayed any decrease over the last 20 years ${ }^{(4)}$. Infertility causes great worry and sorrow for many couples in Africa, especially for the women. Medical evidence shows that men and women usually have the same rates of infertility ${ }^{(12)}$.Yet African tradition continues to view infertility as a woman's fault $^{(12)}$.

Knowledge is a key factor associated with fertility self-care (that is knowing about your own fertility potential) and the initiation of treatment (when needed), concluding that education about fertility issues is needed to prevent fear and unnecessary delay in seeking help when faced with problems conceiving ${ }^{(3)}$. Knowledge about fertility health issues may also help prevent infertility in the first instance; for example more information and advice regarding curable sexually transmitted diseases could reduce the number of cases of infertility, particularly in less developed countries where most cases of infertility are due to infection (13). Infertility in Nigeria is found to be mainly related to post infectious causes; sexually transmitted infections, post abortal and puerperal sepsis ${ }^{(14)}$, poor knowledge of the fertile period of the menstrual cycle-the period of ovulation, uterine anomalies and diseases, and male factor from inadequate sperm count.

Despite this large burden of infertility in Nigeria, very few infertility management programs exist. Fertility care, its development and access is limited in resource-poor countries ${ }^{(15)}$ like Nigeria, overshadowed by competing and more important reproductive health issues ${ }^{(16)}$ like high maternal mortality rates. Most times the burden of infertility lies squarely on the couple alone, with a greater burden on the woman. To achieve pregnancy, infertile couples may resort to different forms of treatment. Likewise, the financial burden of treating infertility is high. Given the poverty that exists in Nigeria, where $92.4 \%$ of the population live on less than 2 USD a day, the high cost of infertility treatments is associated with a significant risk of catastrophic health expenditure. For example, tubal disease, which is the most common cause of infertility in Nigeria, is best treated with in-vitro fertilization (IVF), and one cycle of IVF in Nigeria costs an average of 3,289 USD. This out-of-pocket payment has the potential to create or exacerbate poverty.

In Nigeria, there are many misconceptions about infertility, and a research into the knowledge and the health seeking behaviour of men and women with infertility will likely bring out their understanding on infertility and its treatment. The study conducted in 10 countries across Europe, Asia, Africa and South America revealed that the knowledge on infertility is low (World Fertility Awareness Month, 2006). There are very few published study on knowledge of infertility among men and women in Nigeria. It is on this claim that this study aims to investigate the knowledge, perceptions, myths and health seeking behaviour on infertility among men and women that attend some selected hospital in Ogun state, Nigeria.

\section{METHODS}

\section{Study site and Study design}

A cross-sectional survey was conducted on a conveniently selected adult population, recruited from the outpatient centres of a tertiary care hospital in Abeokuta, Ogun state 
(Federal Medical Centre Abeokuta) and a State hospital in Ota, Ogun state (State Hospital Ota). These two hospitals were chosen because they are the largest Government hospitals in two of the Ogun state Senatorial districts, and people from all socio-economic and ethnic backgrounds visit these centres. An outpatient centre was chosen at each hospital, which had designed waiting area for patients and people accompanying them for their gynaecology doctor's visit.

\section{Recruitment and Interview}

The patients that presented at the gynaecology out-patient centres were approached by the study team members. After taking a written informed consent, participants were interviewed one-on-one at the designated locations, where privacy was ensured. Each interview was conducted by a team member who had undergone previous training. The interview was conducted in the native language of Yoruba (English language was used for those that doesn't understand Yoruba language), using a structured, pre-tested questionnaire and lasted for 12-15 minutes.

\section{Sample Size}

Using the formula $\left(\mathrm{z}^{2} \times \mathrm{p} \times \mathrm{q}\right) / \mathrm{d}^{2}$ a sample size of 246 was calculated with the confidence interval of $95 \%$ and precision of $5 \%$. The sample size was inflated by $20 \%$ to account for non-responders. Therefore, the adjusted sample size was approximately 272 .

\section{Questionnaire}

The questionnaire was initially designed by the research team on the basis of previously published literature on infertility. It was designed in English language and translated for patients that doesn't understand the language. It was thoroughly discussed amongst the study team and external experts to reduce any bias and to standardize the terms.

The questionnaire was divided into various subsections, the first assessed the knowledge of infertility and the next evaluated the perception of infertility. The final section inquired about their health seeking behaviour

\section{Statistical Analysis}

Data was coded and entered using EpiData v 3.2. Data-based files were exported to SPSS v25.0 to be analysed. Associations were assessed using Coefficient of Correlation and Regression, a p-value of $\leq 0.05$ was taken as significant.

\section{Ethical Considerations}

The research protocol was reviewed and approved by Babcock University Health Research and Ethics committee (BUHREC). All subjects had the right to withdraw from the study anytime they wished without giving any explanation. The questionnaire was anonymous and ensured confidentiality of the study participants. Written informed consent was taken from each participant prior to the interview. 


\section{RESULTS}

\section{Socio-Demographic Characteristics of the Sample}

Two hundred and seventy-two questionnaires were completely and correctly filled, and analysis was done on these completely filled questionnaires (272). The socio demographic characteristics of the respondents are shown in table 1 . The respondent's ages ranged from 17 to 69 years with a mean of $33.27 \pm 8$.7years. The ages of the majority of the respondents $149(54.8 \%)$ fell within the 27 to 36 years age range. Majority of the respondents were female $204(75 \%)$. Most 172(63.2\%) of the respondents were of the Christian faith and 149(54.8) of the respondents had a tertiary education. Less than half $131(48.2 \%)$ of the respondents were self-employed and majority of the respondents were married $220(80.9 \%)$.

Table 1 Socio-demographic Characteristics of the Respondents

\begin{tabular}{|c|c|c|}
\hline \multirow[t]{2}{*}{ Socio-demographic variables for consideration } & \multicolumn{2}{|c|}{ Respondents in this study; $\mathrm{N}=272$} \\
\hline & Frequency(n) & Percentage $(\%)$ \\
\hline \multicolumn{3}{|l|}{ Age (in years) $\bar{x} 30 \pm 6.64$} \\
\hline $17-26$ & 51 & 18.8 \\
\hline $27-36$ & 149 & 54.8 \\
\hline $37-46$ & 53 & 19.5 \\
\hline $47-56$ & 14 & 5.1 \\
\hline $57-66$ & 2 & .7 \\
\hline $67-76$ & 3 & 1.1 \\
\hline \multicolumn{3}{|l|}{ Religion } \\
\hline Christian & 172 & 63.2 \\
\hline Islam & 100 & 36.8 \\
\hline \multicolumn{3}{|l|}{ Education } \\
\hline primary & 29 & 10.7 \\
\hline secondary & 94 & 34.6 \\
\hline Tertiary & 149 & 54.8 \\
\hline \multicolumn{3}{|l|}{ Marital Status } \\
\hline Single & 41 & 15.1 \\
\hline Married & 220 & 80.9 \\
\hline Divorced & 11 & 4.0 \\
\hline \multicolumn{3}{|l|}{ Occupation } \\
\hline Civil servant & 49 & 18.0 \\
\hline Self-employed & 131 & 48.2 \\
\hline Trading & 65 & 23.9 \\
\hline Driver & 6 & 2.2 \\
\hline Artisan & 3 & 1.1 \\
\hline Farming & 18 & 6.6 \\
\hline \multicolumn{3}{|l|}{ Sex } \\
\hline Male & 68 & 25.0 \\
\hline Female & 204 & 75.0 \\
\hline
\end{tabular}




\section{Knowledge About infertility}

More than half 147(54\%) of the respondents knew that both man and woman are responsible for delay in achieving pregnancy among couples. Majority 164(60.3\%) of the respondents knew that infections like urinary tract infection caused by gonorrhoea, and medical conditions like diabetes, hypertension, obesity amongst others could cause infertility among couples. Less than half $107(39.3 \%$ ) of the respondents stated that waywardness/promiscuity would cause infertility among couples. A small proportion $97(35.7 \%)$ of the respondents stated that supernatural causes such as ancestral curse would be responsible for infertility among couples. Slightly more than $138(50.7 \%)$ of the respondents' had the intuition that early marriage would cause infertility among couples while $135(49.6 \%)$ of the respondents stated that late marriage cannot cause infertility among couples.

More than half $149(54.8 \%)$ of the respondents knew that low sperm count would cause infertility among couples. Majority $181(66.5 \%)$ of the respondents knew that trauma to the reproductive organs would cause infertility among couples. Most 170(62.5\%) of the respondents stated that unsafe abortion would cause infertility among couples. More than half $147(54 \%)$ of the respondents acknowledged to the fact that over work or stress could cause infertility in couples. More than half 164(60.3\%) of the respondents stated that family planning drugs could cause infertility among couples. Few 78(28.7\%) of the respondents reported that use of sexuality arousing drugs can not cause infertility in couples. More than half $146(53.7 \%)$ of the respondents stated that heredity or family problem can cause infertility among couples. Less than half 103(37.9\%) of the respondents know that failure to worship the family gods cannot result to infertility among couples. Few 101(37.1\%) of the respondents were stated that men using their manhood to get money can cause infertility among couples, while $95(34.9 \%)$ of the respondents knew that God not allotting children to some people cannot cause infertility. Majority 238(87.5\%) of the respondents knew that infertility could prevented, of those who stated that infertility can be prevented reported the following means, health education on reproduction 225(94.5\%), fertility awareness 226 $(95 \%)$, and early treatment of sexually transmitted disease $236(99.1 \%)$ (Table 2)

Majority 209(76.8\%) of the respondents knew that infertility could be treated. of those who knew that infertility could be treated stated the following ways of treatment: native concoction 132(63.16\%), visiting spiritual houses (churches/ mosques) 97(46.41\%), undergoing regular test/examination and treatment of ailments 191(91.39\%), in vitro fertilization 145(69.37\%), God will do it at his own time 141(67.46\%) (See, Table 3).

Furthermore, respondent's knowledge of infertility measured on a 27 points knowledge scale, rating showed a mean score of $14.81 \pm 3.48$. More than half of the respondents $174(64 \%)$ had adequate knowledge regarding the perceived causes of infertility while $92(33.3 \%)$ had an excellent knowledge regarding the perceived causes of infertility, only a small percentage of the respondents had poor knowledge on the perceived causes of infertility $6(2.2 \%)$ (See, Table 4). 
African Journal of Health, Nursing and Midwifery

ISSN: 2689-9418

Volume 4, Issue 4, 2021 (pp. 86-100)

www.abjournals.org

Table 2: Respondents Knowledge about Infertility

\begin{tabular}{|c|c|c|}
\hline \multirow[t]{2}{*}{ Items } & \multicolumn{2}{|c|}{$\begin{array}{l}\text { Respondents in this } \\
\text { study }=272, * N=238\end{array}$} \\
\hline & Frequency(n) & Per cent $(\%)$ \\
\hline \multicolumn{3}{|l|}{ Who is responsible for the delay in pregnancy among } \\
\hline & 28 & 10.3 \\
\hline Male only & 45 & 16.5 \\
\hline Woman & 147 & 54.0 \\
\hline Both & 52 & 19.1 \\
\hline \multirow{2}{*}{\multicolumn{3}{|c|}{$\begin{array}{l}\text { *None of them } \\
\text { Cause infertility among couples? }\end{array}$}} \\
\hline & & \\
\hline $\begin{array}{l}\text { *Diseases (e.g., urinary tract infection, gonorrhoea, } \\
\text { diabetes, hypertension obesity etc) }\end{array}$ & 164 & 60.3 \\
\hline *Waywardness/promiscuity & 107 & 39.3 \\
\hline Supernatural cause e.g., curse & 97 & 35.7 \\
\hline Early marriage & 138 & 50.7 \\
\hline *Late marriage & 102 & 37.5 \\
\hline *Low sperm count & 149 & 54.8 \\
\hline *Trauma to the reproductive organs & 181 & 66.5 \\
\hline *Unsafe abortion & 170 & 62.5 \\
\hline *Over work or stress & 147 & 54.0 \\
\hline *Family planning drugs & 164 & 60.3 \\
\hline Use of sexuality arousing drugs & 78 & 28.7 \\
\hline Heredity or family problem & 89 & 32.7 \\
\hline Failure to worship the family gods & 103 & 37.9 \\
\hline *Men using their manhood to get money & 101 & 37.1 \\
\hline God not allotting children to some people & 95 & 34.9 \\
\hline \multicolumn{3}{|l|}{ Can infertility be treated? } \\
\hline Yes & 238 & 87.5 \\
\hline No & 34 & 12.5 \\
\hline \multicolumn{3}{|l|}{ *+Ways of preventing infertility? } \\
\hline $\begin{array}{l}\text { Health education on reproduction/sexual life for } \\
\text { teenagers }\end{array}$ & 225 & 94.5 \\
\hline Fertility awareness & 226 & 95 \\
\hline Early treatment of sexually transmitted diseases & 236 & 99.1 \\
\hline $\begin{array}{l}\text { Clinical screening for abnormalities and hormonal } \\
\text { imbalance }\end{array}$ & 193 & 81.1 \\
\hline
\end{tabular}

+ Multiple responses 
African Journal of Health, Nursing and Midwifery

ISSN: 2689-9418

Volume 4, Issue 4, 2021 (pp. 86-100)

www.abjournals.org

Table 3: Respondents Knowledge about Infertility

\begin{tabular}{|c|c|c|}
\hline \multirow{2}{*}{$\begin{array}{l}\text { Variables } \\
\text { **Ways of treating infertility in men and women }\end{array}$} & Frequency $(n=209)$ & Percentage $(\%)$ \\
\hline & & \\
\hline The use of native concoction & 132 & 63.16 \\
\hline Visiting spiritual houses churches and mosque & 97 & 46.41 \\
\hline $\begin{array}{l}\text { Undergoing regular test/examination and treatment } \\
\text { of ailments that can delay child bearing }\end{array}$ & 191 & 91.39 \\
\hline Adoption or IVF in vitro fertilizer & 145 & 69.37 \\
\hline $\begin{array}{l}\text { No treatment is needed, God will do it at his own } \\
\text { time }\end{array}$ & 141 & 67.46 \\
\hline
\end{tabular}

**Multiple responses

Table 4. Proportion of Respondent's Infertility

\begin{tabular}{lll}
\hline & \multicolumn{2}{l}{ Respondents in this study; $\mathbf{N = 2 7 2}$} \\
\cline { 2 - 3 } Poor (0-9.9) & Frequency & Percentage $(\%)$ \\
Adequate (10-18.9) & 6 & 2.2 \\
Excellent (19-27) & 174 & 64.0 \\
\hline
\end{tabular}

\section{Perception of Infertility}

As shown in table 5. below, that less than half 108(39.7\%) of the respondents perceived that infertile couple will achieve pregnancy after being managed or received treatment, while $24(8.8 \%)$ of the respondents strongly disagreed that spiritual means is the best way to treat infertile couples. Only $81(29.8 \%)$ of the respondents seems to be of the opinion that orthodox method is the effective means of managing infertility in couples. Few 84(30.9\%) of the respondents perceived with a strong opinion that the only way to manage infertility in couples is through medical treatment. Less than half 102(37.5\%), of the respondents does not concur to the statement that it is easier and cheaper to manage infertility in men than in women. Less of than half $100(36.8 \%)$ of the respondents disagreed that infertility is not a serious problem, while $91(33.5 \%)$ opposed to the idea that infertility is only serious in African society. $102(37.5 \%)$ seems not to agree that there is no cause for alarm, that only those who are under spell becomes infertile.

In addition, respondent's perception of infertility measured on a 27-point rating scale, showed a mean of $14.45 \pm 3.52$, with majority of the respondents $215(64 \%)$ had adequate perception of infertility, 32(11.8\%) of the respondents had excellent perception of infertility with only $25(9.2 \%)$ of the respondents with low perception (See, Table 6). 
African Journal of Health, Nursing and Midwifery

ISSN: 2689-9418

Volume 4, Issue 4, 2021 (pp. 86-100)

www.abjournals.org

Table 5: Respondents Perception of Infertility in Couple N=272

\begin{tabular}{|c|c|c|c|c|}
\hline Statements & $\begin{array}{l}\text { Strongly } \\
\text { disagree } \\
* * \mathbf{F}(\%)\end{array}$ & $\begin{array}{l}\text { Disagree } \\
\text { F }(\%)\end{array}$ & $\begin{array}{l}\text { Agree } \\
\text { F (\%) }\end{array}$ & $\begin{array}{l}\text { Strongly } \\
\text { agree } \\
\text { F (\%) }\end{array}$ \\
\hline $\begin{array}{l}\text { Infertile couple will achieve pregnancy } \\
\text { after being managed/receiving treatment }\end{array}$ & $13(4.8)$ & $45(16.5)$ & $106(39.0)$ & $* 108(39.7)$ \\
\hline $\begin{array}{l}\text { Spiritual means is the best way to treat } \\
\text { infertile couples }\end{array}$ & $* 24(8.8)$ & $102(37.5)$ & $101(37.1)$ & $45(16.5)$ \\
\hline $\begin{array}{l}\text { Orthodox method is the effective means } \\
\text { of managing infertility }\end{array}$ & $* 19(7.0)$ & $76(27.9)$ & $96(35.3)$ & $81(29.8)$ \\
\hline $\begin{array}{l}\text { The only reliable way of managing } \\
\text { infertile couple is through medical } \\
\text { treatment }\end{array}$ & $21(7.7)$ & $67(24.6)$ & $100(36.8)$ & $* 84(30.9)$ \\
\hline $\begin{array}{l}\text { It is easier and cheaper to manage } \\
\text { infertility in men than women }\end{array}$ & $* 12(4.4)$ & $102(37.5)$ & $106(39.0)$ & $52(19.1)$ \\
\hline $\begin{array}{l}\text { It is easier and cheaper to manage } \\
\text { infertility in women than men }\end{array}$ & $* 35(12.9)$ & $100(36.8)$ & $90(33.1)$ & $47(17.3)$ \\
\hline It is only serious in Africa society & $* 51(18.8)$ & $91(33.5)$ & $78(28.7)$ & $52(19.1)$ \\
\hline $\begin{array}{l}\text { No cause for alarm, only those who are } \\
\text { under a spell becomes infertile }\end{array}$ & $* 43(15.8)$ & $102(37.5)$ & $79(29.0)$ & $48(17.6)$ \\
\hline
\end{tabular}

*Expected Responses

Table 6. Proportion of Respondent's Perception of Infertility

\begin{tabular}{lll}
\hline & \multicolumn{2}{l}{ Respondents in this study; $\mathbf{N}=\mathbf{2 7 2}$} \\
\cline { 2 - 3 } & Frequency & Percentage $(\%)$ \\
Low(0-9.9) & 25 & 9.2 \\
Adequate $(10-18.9)$ & 215 & 79.0 \\
Excellent $(19.9-27)$ & 32 & 11.8 \\
\hline
\end{tabular}

\section{Myths about Infertility as Reported by the Respondents}

Few $72(26.5 \%)$ of the respondents believed that infertility is caused by witches and wizards while $139(51.1 \%)$ believed on the contrary. Less than half $96(35.3 \%)$ of the respondents accepts that infertility is caused by watery sperm. Less than half $63(23.2 \%)$ of the respondents believed that infertility is caused by early circumcision. Few $58(21.3 \%)$ of the respondents, believed that infertility is caused by eating certain foods or vegetables e.g., Okra. Above a quarter $86(31.6 \%)$ of the respondents, tends to agree to the myths that female holding their feet high after sexual intercourse and not going to the bathroom immediately after can increase conception. Few 73(26.8\%) of the respondents believed that adopting a child increases the chances of getting pregnant. While, $89(32.7 \%)$ of the respondents believed that giving alms can enhance fertility. Less than half $111(40.8 \%)$ of the respondents believed that infertility is caused by EDA (sperm back flow). Almost half 126(46.3\%) of the respondents believed that infertility has more negative effects on women than on men. Less than half $123(45.2 \%)$ of the respondents are of the opinion that delay in ability to achieve pregnancy /infertility could be inherited from parents (See, Table 7.). 
African Journal of Health, Nursing and Midwifery

ISSN: 2689-9418

Volume 4, Issue 4, 2021 (pp. 86-100)

www.abjournals.org

Table 7. Myths About infertility as Reported by the Respondents'

\begin{tabular}{|c|c|c|c|}
\hline Statements & $\begin{array}{l}\text { Agree } \\
\text { F }(\%)\end{array}$ & $\begin{array}{l}\text { Disagree } \\
\text { F }(\%)\end{array}$ & $\begin{array}{l}\text { Not sure } \\
\text { F }(\%)\end{array}$ \\
\hline $\begin{array}{l}\text { Infertility is caused by witches and } \\
\text { witchcraft }\end{array}$ & $72(26.5 \%)$ & $139(51.1 \%)$ & $61(22.4 \%)$ \\
\hline Infertility is caused by watery sperm & $96(35.3 \%)$ & $132(48.5 \%)$ & $44(16.2 \%)$ \\
\hline $\begin{array}{l}\text { Infertility is caused by early circumcision } \\
\text { of male child }\end{array}$ & $63(23.2 \%)$ & $166(61.0 \%)$ & $43(15.8 \%)$ \\
\hline $\begin{array}{l}\text { Infertility is caused by eating certain foods } \\
\text { or vegetable e.g., okra. }\end{array}$ & $58(21.3 \%)$ & $162(59.6 \%)$ & $52(19.1 \%)$ \\
\hline $\begin{array}{l}\text { The female holding their feet high after } \\
\text { sexual intercourse and not going to the } \\
\text { bathroom immediately can increase } \\
\text { conception }\end{array}$ & $86(31.6 \%)$ & $129(47.4 \%)$ & $57(21.0 \%)$ \\
\hline $\begin{array}{l}\text { Adopting a child increases the chances of } \\
\text { getting pregnant }\end{array}$ & $73(26.8 \%)$ & $145(53.3 \%)$ & $54(19.9 \%)$ \\
\hline Giving alms can enhance fertility & $89(32.7 \%)$ & $136(50.0 \%)$ & $47(17.3 \%)$ \\
\hline $\begin{array}{l}\text { Taking care of children around can enhance } \\
\text { fertility }\end{array}$ & $78(28.7 \%)$ & $146(53.7 \%)$ & $48(17.6 \%)$ \\
\hline Contraceptive use causes infertility & $88(32.4 \%)$ & $136(50.0 \%)$ & $48(17.6 \%)$ \\
\hline Male don't have infertility issues & $89(32.7 \%)$ & $134(49.3 \%)$ & $49(18.0 \%)$ \\
\hline $\begin{array}{l}\text { Infertility is caused by EDA } \text { \{sperm back } \\
\text { flow\} }\end{array}$ & $111(40.8 \%)$ & $127(46.7 \%)$ & $34(12.5 \%)$ \\
\hline $\begin{array}{l}\text { Infertility has more negative effect on } \\
\text { women than on men }\end{array}$ & $126(46.3 \%)$ & $112(41.2 \%)$ & $34(12.5 \%)$ \\
\hline $\begin{array}{l}\text { Delay in ability to achieve } \\
\text { pregnancy/infertility could be inherited } \\
\text { from parents? }\end{array}$ & $123(45.2 \%)$ & $121(44.5 \%)$ & $28(10.3 \%)$ \\
\hline
\end{tabular}

\section{Respondents Health-Seeking Behaviour for Infertility}

Less than half $120(44.1 \%)$ of the respondents reported that they often go to a traditional birth attendant for help. Less than half $109(40.1 \%)$ of the respondents reported that they often check the internet for self-mediations concerning my infertility. Less than half 115(42.3\%) of the respondents reported that they often had other sources for seeking infertility services which includes; native doctors, herbalist. Few 99 (36.4\%) of the respondents reported that they often go to religious home to treat infertility. Less than half $101(37.1 \%)$ of the respondents reported that they sometime booked appointments with the doctors when having infertility issues (See, Table 8.). 
Furthermore, as shown in table 9 . below, on a 10 points scale, rating, respondents mean score was $4.35 \pm 2.66$, it was observed that majority $191(70.2 \%)$ of the respondents had low health seeking behaviour.

Table 8. Respondent's Health Seeking Behaviour Regarding Infertility

$\mathbf{N}=\mathbf{2 7 2}$

\begin{tabular}{|c|c|c|c|}
\hline Items & $\begin{array}{l}\text { Sometimes } \\
\text { F (\%) }\end{array}$ & $\begin{array}{l}\text { Often } \\
\text { F }(\%)\end{array}$ & $\begin{array}{l}\text { Never } \\
\text { F }(\%)\end{array}$ \\
\hline I go to a traditional birth attendant for help & $120(44.1)$ & $98(36.0)$ & $54(19.9) *$ \\
\hline $\begin{array}{l}\text { I check the internet for self-mediations } \\
\text { concerning my infertility }\end{array}$ & $109(40.1)$ & $99(36.4)$ & $64(23.5)^{*}$ \\
\hline $\begin{array}{l}\text { Other sources for seeking infertility services } \\
\text { includes; native doctors, herbalist }\end{array}$ & $115(42.5)$ & $71(26.1)$ & $86(31.6)^{*}$ \\
\hline $\begin{array}{l}\text { I go to religious home for treatment of } \\
\text { infertility }\end{array}$ & $99(36.4)$ & $80(29.4)$ & $93(34.2)^{*}$ \\
\hline $\begin{array}{l}\text { I book appointments with the doctors when } \\
\text { having infertility issues }\end{array}$ & $100(36.8)$ & $101(37.1)$ & $71(26.1)^{*}$ \\
\hline
\end{tabular}

*Expected Responses

Table 9. Proportion of Respondents Health-Seeking Behaviour

\begin{tabular}{lll}
\hline & \multicolumn{2}{l}{ Respondents in this study; $\mathbf{N}=272$} \\
\cline { 2 - 3 } Low (0-5) & Frequency & Percentage $(\%)$ \\
High (6-10) & 191 & 70.2 \\
\hline
\end{tabular}

\section{DISCUSSION}

The results of this study indicated that knowledge about the cause of infertility is adequate in the study population. For instance, more than half of the participants attested to the fact that infertility is caused by both men and women, This finding corroborated the reports of Hanna and Gough, 2016, Malik \& Coulson, 2008), Himmel et al., (2005), and Kahlor \& Mackert, (2009) which stated that both partners are responsible for infertility, this finding also supports the Centre of Disease Control (2010) findings that infertility is a problem that affects men and women of reproductive ages in all areas of the world. The adequate knowledge of the respondents was further confirmed upon discovering that a good number of the respondents also had the understanding that urinary tract infections such as gonorrhea, and medical conditions like diabetics, hypertension obesity amongst others could cause infertility among couples. This support the findings by world health organization (2014) that stated that previous infections in the genital tract play a very important role in causing infertility; it further stated that One third of the women in developed countries complaining of infertility showed evidence of previous pelvic infections, including blocked tubes. Similar numbers were found in Asian and Latin American countries, but in the African countries, nearly twice 
as many women had causes related to previous infection. In fact, 40 per cent of African women who had been pregnant had tubal blockage. Majority of the respondents, agreed that unsafe abortion can lead to infertility and this corroborates the qualitative study carried out by Tabong and Adongo (2013), and Amoran et al (2016) where it was reported that abortions in all forms (safe and unsafe) are believed to cause infertility, most especially those conducted by unqualified individuals. One of the causes of infertility that the respondents supported was the one caused by low sperm count. This was also supported by Sumera et al (2011) that the most common cause of male infertility is due to sperm production in the testes. There was a significant relationship between the respondent's knowledge and their health seeking behavior. This finding is similar to the findings of Tabong \&Adongo (2013).

Majority of the respondents agreed that infertility can be treated. Infertility was seen as a minute problem since it can be treated which corroborates the American Society for Reproductive Medicine study, (2011); which stated that the factors affecting fertility are easily detected and treated. As regards the aspect of management, majority believed that if it is properly managed the couples could achieve pregnancy and this corroborates the findings of Sumera et al (2011), that majority of the respondents believed that couples should seek treatment for infertility. The study also revealed that there was a significant relationship between respondents' perception of infertility and their health-seeking behaviour.

A small proportion of the respondents disagreed that supernatural cause such as ancestral curse is responsible for infertility among couples. This may be due to their religion which they practice and their level of education, as this was at variance with the documentation of Sumera et al (2011) and Tabong and Adongo (2013). Sumera et al (2011) stated that there is a prevalent belief in the society that infertility can be caused by supernatural causes like black magic; the less educated respondents were more likely to attribute the causes of infertility to evil forces or supernatural power outside human control.

Few of the respondents believed that infertility is caused by witches and wizards. Less than half of the respondents accepted that infertility is caused by watery sperm. Less than half of the respondents believed that infertility is caused by early circumcision. Few of the respondents, believed that infertility is caused by eating certain foods or vegetables e.g., Okra. This finding is similar to the result of Bunting and Boivin (2008) that women would achieve pregnancy due to eating the recommended number of fruits and vegetables in a day. Above a quarter of the respondents, tends to agree to the myths that female holding their feet high after sexual intercourse and not going to the bathroom immediately after can increase conception. This corroborate the findings of Daniluk (2001) that standing on your head that would keep the oocyte and sperm in closer contact and facilitate fertilization. Few of the respondents believed that adopting a child increases the chances of getting pregnant. This finding is similar to the report of Bunting and Boivin (2008) that women conceiving naturally immediately after adopting a child. Although all are relatively harmless in that they do not involve risky behaviour, there is no empirical research that these factors have an effect on pregnancy. Less than half of the respondents believed that infertility is caused by EDA (sperm back flow). Almost half of the respondents believed that infertility has more negative effects on women than on men. Less than half of the respondents are of the opinion that delay in ability to achieve pregnancy /infertility could be inherited from parents

The findings revealed that majority of the respondents had poor health-seeking behaviour on infertility. This finding is at variance with the findings of Sumera et al (2011) and Tabong \& 
Adongo (2013). Less than half of the respondents reported that they often go to a traditional birth attendant for help. Less than half of the respondents reported that they often check the internet for self-mediations concerning their infertility. Less than half of the respondents reported that they often had other sources for seeking fertility services which includes; native doctors, herbalist. Few of the respondents reported that they often go to religious home to treat infertility. Less than half of the respondents reported that they sometime booked appointments with the doctors when having infertility issues.

\section{Limitations of the Study}

Respondents may have been biased in giving responses to some items (Such as health seeking behaviour) since data received was based on self-reported information.

Due to limited time and money the researcher could not work with the total population.

\section{RECOMMENDATION}

There is a need for health education in re-orienting the couple that infertility could be caused by either partner or both. Community-based health education programmes should be organised using existing male and female platforms to promote right knowledge and perception of respondents with regards to early diagnosis and management of infertility. It was mentioned that sexually transmitted infections such as gonorrhea can lead to pelvic inflammatory disease and tubal blockage. Therefore, there is a need to educate the general public about safer sex and avoidance of multiple sexual partners to prevent sexually transmitted infection and its sequel. And finally, government should establish infertility clinic with sophisticated equipment and personnel, this could encourage the use of orthodox medicine for infertility treatment.

\section{CONCLUSION}

In conclusion, childbearing and family are considered a right of every human being Infertility is a fairly common problem affecting approximately one-fifth of the population. This study showed that the respondents had adequate knowledge and majority had adequate perception of infertility. Few of the respondents, believed that infertility is caused by eating certain foods or vegetables. Majority of the respondent's health seeking behaviour includes the use of traditional and orthodox medicine. Majority of the respondents had poor health-seeking behaviour. There was a relationship between respondent's perception and their healthseeking behaviour.

\section{Acknowledgement}

Part of this research was supported and funded by Mrs Amusan, Grace Oluwatosin.

\section{Conflicts of interest}

There was no conflicts of interest. 


\section{REFERENCES}

[1] Hoseinighochani, F., \& Zargham, H. (2014). Women's experience of female infertility. Iranian Journal of Reproductive Medicine, 12(45). 761-65

[2] Hardee, K., Gay, J., \& Blanc, A. K. (2012). Maternal morbidity: Neglected dimension of safe motherhood in the developing world. Global Public Health, 7(6), 603-617.

[3] Boivin, J., Bunting, L., Collins, J. A., \& Nygren, K. G. (2007). International estimates of infertility prevalence and treatment-seeking: potential need and demand for infertility medical care. Human Reproduction, 22(6), 1506-1512.

[4] World Health Organization. (2014b). WHO Infertility is a global public health issue. Retrieved October 21, 2014, from file:///WHO\%20_\%20Infertility\%20is\%20a\%20global\%20public\%20health\%20issue. ht $\mathrm{m}$

[5] Hart, D., Norman, J., Callander, R., \& Ramsden, L. (2000). Gynaecology illustrated (5th ed., p. 390). New York: Harcourt publishers limited.

[6] Mascarenhas, M. N., Flaxman, S. R., Boerma, T., Vanderpoel, S., \& . Stevens, G. A. (2012). PLOS Medicine: National, regional, and global trends in infertility prevalence since 1990: A Systematic analysis of 277 health surveys. Retrieved October 9, 2014, from http://www.plosmedicine.org/article/info\%3Adoi\%2F10.1371\%2Fjournal.pmed.10013 56 \#pmed-1001356-g005

[7] Oakley, L., Doyle, P., \& Maconochie, N. (2008). Lifetime prevalence of infertility and infertility treatment in the UK: results from a population-based survey of reproduction, 23(2).

[8] Centers for Disease Control and Prevention (2011): Reproductive health/infertility. |lhttp://www.cdc.gov/data_stat

[9] Akwame, B. (2013). The Problem of infertility in Africa. The human life review. Retrieved October 21, 2014, from http://www.humanlifereview.com/the-problem-ofinfertility-inafrica/

[10] Callister, L. C. (2010). Global Infertility: Are we caring yet? MCN, The American Journal of Maternal/Child Nursing, 35(3), 174. Http://doi.org/10.1097/NMC.0b013e3181d760be

[11] Ombelet, W., Cooke, I., Dyer, S., Serour, G., \& Devroey, P. (2008). Infertility and the provision of infertility medical services in developing countries. Human Reproduction Update, 14(6), 605-621. Http://doi.org/10.1093/humupd/dmn042

[12] Human Life Foundation, (2013). The Problem of Infertility in Africa - The Human Life Review. Http://www.humanlifereview.com/the-problem-of-infertility-in-africa/, accessed October 21, 2014.

[13] Larsen U. Trends in infertility in Cameroon and Nigeria. Int Fam Plan Perspect[online].1995[cited 2012 Oct 3]; 138-43. Available from:http://www.jstor.org/stable/10.2307/2133320

[14] Araoye OM. Epidemiology of infertility: social problems of the infertile couples. West Afr J Med. 2003;22(2):190-6

[15] James PB, Taidy-Leigh L, Bah AJ, Kanu JS, Kangbai JB, Sevalie S. Prevalence and Correlates of Herbal Medicine Use among Women Seeking Care for Infertility in Freetown, Sierra Leone. Evidence-Based Complementary and Alternative Medicine, vol 2018, Article ID 9493807, 11 pages, 2018. Https:// doi.org/10.1155/2018/9493807. 
[16] Patel M. The socioeconomic impact of infertility on women in developing countries. Facts, Views and Vision in Obstetrics and Gynaecology. 2016;8(1): 59-61

[17] Sumera Ali, Raafay Sophie, Ayesha M. Imam, Faisal I. Khan, Syed F. Ali, Annum Shaikh and Syed Farid-ul-Hasnain, 2011. Knowledge, Perceptions and Myths regarding Infertility among selected adult Population in Pakistan: A Cross-sectional study. BMC Public Health. October 4; 11:760.

[18] Tabong P.T and Adongo P.B, 2013. Understanding the Social Meaning of Infertility and Childbearing: Qualitative Study of the Perception of Childbearing and Childlessness in Northern Ghana. Plos ONE 8(1): e54429. Doi:10.1371/journal.pone.0054429

[19] Daniluk J: The Infertility Survival Guide: Everything You Need To Know To Cope With The Challenges While Maintaining Your Sanity, Dignity and Relationships. California: New Harbinger Publications; 2001.

[20] Onah HE, Agbata TA, Obi SN: Attitude to sperm donation among medical students in Enugu, South-Eastern Nigeria. J Obstet Gynaecol 2008, 28(1):96-99.

[21] Inhorn MC: Making Muslim babies: IVF and gamete donation in Sunni versus Shi'a Islam. Cult Med Psychiatry 2006, 30(4):427-450. 